\title{
INDEPENDENT LEARNING THROUGH YOUTUBE: PUPPETRY ARTS LEARNING FOR THE DUO PUPPETEER BROTHERS
}

\author{
Amrina Rosyada ${ }^{1}$, Dendi Pratama ${ }^{2}$, Widya $^{3}$ \\ ${ }^{1,3}$ English Education Program, Faculty of Languages and Art, Universitas Indraprasta PGRI \\ ${ }^{2}$ Politeknik Bina Madani \\ 14mrin4@gmail.com, ${ }^{2}$ riset.dendi@gmail.com, ${ }^{3}$ widya.center@gmail.com
}

\begin{abstract}
Abstrak
Sebagai salah satu bentuk kebanggaan bangsa, seni pedalangan hendaknya disosialisasikan dan dilestarikan kepada generasi penerus. Dibutuhkan media yang kreatif, interaktif, dan berbasis digital sesuai dengan perubahan global yang cepat dan tak terbendung. Penelitian ini bertujuan untuk mendemonstrasikan pemanfaatan YouTube sebagai salah satu platform media yang menarik dan interaktif dalam pembelajaran seni pedalangan secara mandiri bagi duo dalang bersaudara, Prama dan Raffi. Dengan menerapkan desain penelitian kualitatif dengan analisis naratif, penelitian ini melakukan pengamatan, wawancara secara virtual, dan mendokumentasikan secara digital seperangkat kuesioner yang diberikan kepada duo dalang bersaudara. Beberapa data juga dikumpulkan dari sumber sekunder dari kanal Youtube dan berita daring. Tidak seperti dalang kecil lainnya yang belajar seni pedalangan di sanggar, hasil penelitian menunjukkan bahwa duo dalang bersaudara tidak pernah bergabung dengan sanggar seni pedalangan mana pun. Di usianya yang menginjak 16 tahun dan 13 tahun, mereka telah bertahun-tahun mempelajari seni pedalangan melalui kanal Youtube sehingga mereka dapat mengidentifikasi berbagai gaya dalang profesional dalam menampilkan pertunjukan wayang. Melalui kanal Youtube, kedua dalang cilik tersebut dapat menikmati pembelajaran seni pedalangan, sekaligus dapat melestarikan nilai-nilai luhur bangsa dan budaya bangsa.
\end{abstract}

Kata Kunci: pelestarian budaya; pembelajaran mandiri; dalang cilik bersaudara; pembelajaran seni pedalangan; kanal YouTube

\begin{abstract}
As one of the Indonesian honors, puppetry arts are supposed to be socialized and preserved for future generations. It needs creative, interactive, and digital-based media due to the fast and unstoppable global changes. This research aimed to demonstrate the use of YouTube as one of the interesting and interactive media platforms in learning the puppetry arts independently for the duo puppeteer brothers, Prama and Rafi. By applying a qualitative research design with narrative analysis, this research had literally observed, virtually interviewed, and digitally documented a set of questionnaires to the duo puppeteer brothers. Several data were also collected from secondary sources such as YouTube channels and online news. Unlike other little puppeteers who learn the puppetry arts in a studio, the results revealed that the duo puppeteer brothers had never joined any puppetry arts studio. At the age of 16 and 13 years old, they have been learning the puppetry arts through YouTube channels for years to identify different styles of professional puppeteers in performing the puppets' shows. Using YouTube channels, the duo puppeteer brothers enjoy the puppetry arts learning and could preserve the national noble values and culture.
\end{abstract}

Keywords: cultural preservation; independent learning; little puppeteer brothers; puppetry arts learning; YouTube channel

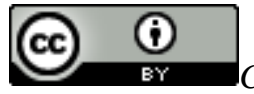

Creative Commons Attribution 4.0 International (CC BY 4.0) 


\section{INTRODUCTION}

Along with the fast and unstoppable global changes, different learning contents are abundant in the digital and online platforms; YouTube has become one of the most popular channels that support people in learning anything they wish (Kennedy, 2016). Since the launch in 2005, YouTube channels have encouraged people at any level of age to learn independently by following the creative and interactive contents of specific issues (Imathiu, 2018; Mujianto, 2019). Moreover, during the pandemic and the emergency online learning where teachers and students have been searching for the best suitable platforms to pursue a qualified learning process; they have indicated the YouTube channels as one of their favorite learning media for its simple, interactive, and attractive media (Mansyur, 2020; Pratiwi \& Puspito Hapsari, 2020; Sari, 2020).

However, there were still several obstacles in utilizing YouTube as the online media learning, particularly for learners who lived in remote areas with limited devices and limited access and unstable internet connections (Agung \& Surtikanti, 2020). Despite those barriers, YouTube has provided the viewers to enjoy any specific issues or subjects with various interesting contents, both in formal education circumstances and non-formal circumstances, including learning the arts and cultures (DeWitt et al., 2013; Pangestika \& Yanuartuti, 2020). In fact, learning through watching the YouTube channels could bring full excitement for the learners in learning independently (Astuti et al., 2021) yet persuaded the effectiveness of the learning outcomes (Kaunang, 2020).

Based on the aforementioned reviews, this study was conducted to recognize the phenomenon of the duo puppeteer brothers who have been learning the puppetry arts independently through YouTube. The phenomenon was interesting since young generations scarcely learned the puppetry arts learning while a noble and modern technology is needed to allure the young generations (Ramdhani \& Ahmad, 2017; Ruastiti et al., 2020). For years, the duo puppeteer brothers have been learning the puppetry arts independently without joining any puppets' studios or communities. The phenomenon was increasingly interesting when the researchers found that the duo puppeteer brothers were not speaking in Javanese language since the duo puppeteer brothers were born and grown up in Jakarta. Although they have Javanese blood from their grandfather of their mother, they have never been communicating in Javanese. Therefore, this study was carried out in accordance the research framework that covered the family circumstances relationship to the duo puppeteer brothers in the puppetry arts learning. Based on the belief that parents are the architects of the children's future achievements, this research would be comprised in research settings and experiences of the duo puppeteer brothers, chronologically.

1. How did the duo puppeteer brothers begin in the puppetry arts learning?

2. How YouTube encourage and support puppetry arts learning for the duo puppeteer brothers?

3. Why is independent learning the selected learning style for the duo puppeteer brothers in the puppetry arts learning?

\section{RESEARCH METHOD}

The research was administered using a qualitative research design with narrative analysis (Creswell, 2012). It covered purposive respondents, detailed information on the respondents' stories and experiences, and their life circumstances, including home, neighborhood, and school environments. The research was started with an observation; searching and classifying literature reviews related to the puppetry arts learning, the use 
of YouTube, and the independent learning; and formatting a set of questionnaires. It continued to distribute the questionnaire to the research respondents and collect the research data. It involved the twoo young puppeteer brothers who have grown up to be teenagers, and their mother and grandfather, who have been eagerly supporting their passion in learning the puppetry arts. In order to validate the data, the research conducted a virtual interview with the respondents, then all collated data was analyzed. Finally, the collated data was interpreted in several themes of chronological settings and illustrated in narrative analysis with several images and descriptions to deliver a comprehensive understanding for the readers. The flow of the research is described in Figure 1.
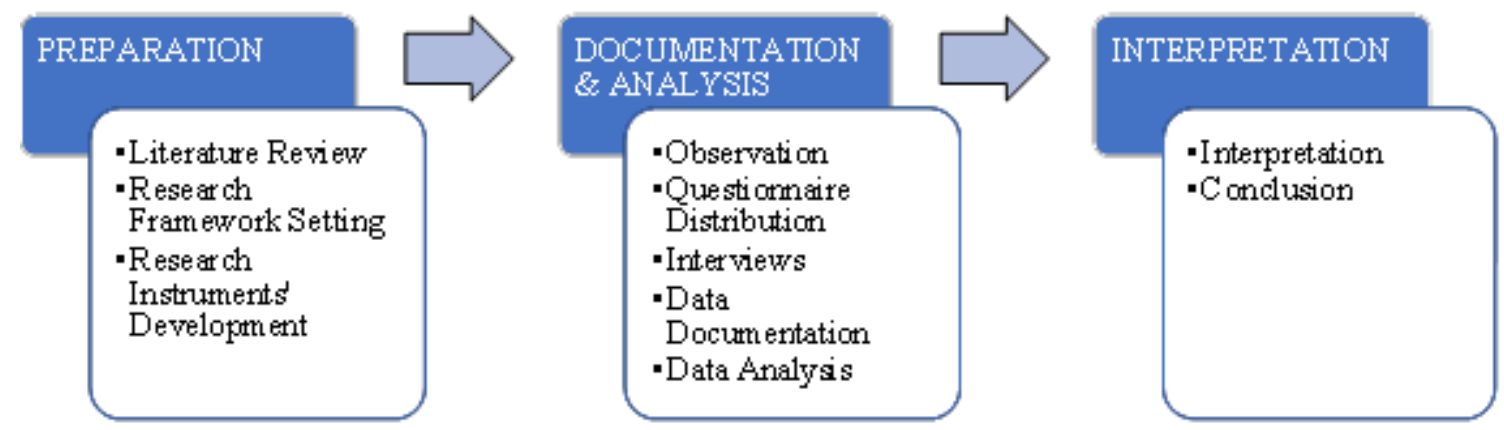

Figure 1 Research step-by-step

\section{RESULT AND DISCUSSION \\ Results}

Based on the collated data from interviews and open-ended questionnaires, findings found that Prama was born in Depok on June 19th, 2005, while Rafi was born on September 21st, 2007, in the same city. Currently, Prama and Rafi live and study in Depok, where Prama joins a state Senior High School, and Rafi participates in a private Islamic Junior High School. Besides puppetry arts, Prama loves to do exercising and play music. Meanwhile, Rafi only loves to play puppetry arts. For both of the puppeteer brothers, the puppetry arts is a unique exciting art, one of the honorable national identities to be preserved. Due to the fast world changes, Prama and Rafi have been thinking that the puppetry arts need to be transformed into more modern shapes; however, traditional figures and media should not be changed. For Prama, the puppetry arts have to be preserved as its persistent stories and settings. However, for Rafi, the puppetry arts have to be preserved but need to be altered for its stories and settings due to world issues (Pratama, 2011).

Nonetheless, both Prama and Rafi agreed to preserve the puppetry arts for future generations. They greatly hoped that the millennials would identify and be proud of the puppetry arts. When people abroad have been proud of the Indonesian traditional puppetry arts, the Indonesian people are supposed to be much more self-respecting of it.

\section{Discussion}

According to the research questions, this section is divided into three different settings, namely: 1) Family circumstances for the duo puppeteer brothers to answer the first question; 2) YouTube as the learning media for the duo puppeteer brothers to answer the second question; and 3) Independent learning for the duo puppeteer brothers to answer the third question. All sections are narrated chronologically and supported by several images. 


\section{Family Circumstances for the Duo Puppeteer Brothers}

The duo puppeteer brothers, Prama and Rafi were introduced to Puppetry Arts since they were at very young age, Prama at his two years old and Rafi at his three years old. In the first place, their grandfather, Prof. Dr. Sumaryoto, the Rector of Universitas Indraprasta PGRI, loved puppetry arts very much and influenced them to recognize and love the puppetry arts. Regarding puppetry arts preservation, the grandfather frequently attracted Prama and Rafi to attend puppetry arts performances. As little boys, Prama and Rafi voluntarily affirmed the offer, and somehow enjoyed the puppetry arts performances. Prama and Rafi even stayed up all night watching the performances excitedly from the very beginning to the end, as the grandfather recognized it as "kuat melek" to his grandchildren.

Unlike other little children who spent most of the time playing gadgets, Prama and Rafi devoted most of their time to watching the puppetry arts performances, whether it was a live show or recorded show. Prama even asked his grandfather to buy him a set of puppets so that Prama could practice what he had just seen from the puppets' show. After watching the puppets' show, the grandfather always acquired Prama with puppets, one by one. Prama was only five years old when his grandfather granted his request with a set of puppets. With the support of grandfather and Prama and Rafi's mother, Ambar Tri Hapsari, Prama and Rafi have been driven to love the puppetry arts as their hobby, particularly for the love of puppeteers.

Moreover, the love of puppetry arts has led them to know more about one of the national honors and heritage. Through the puppetry arts with different figures and characters, different settings, and stories, Prama and Rafi have learned various values of life that influenced them in their real-life circumstances (Iswinarti \& Suminar, 2019). When most millennials adore hero figures from abroad, for Prama and Rafi, the puppetry arts is an honored identity. They stated that the puppetry arts are supposed to be preserved for the next generations, and it is started from Prama and Rafi as the role model.
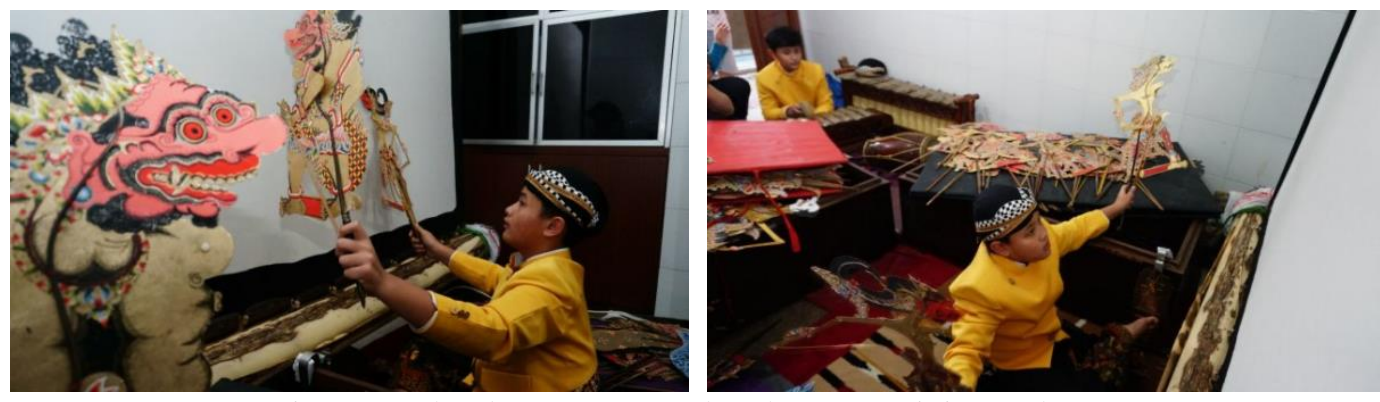

Figure 2 The duo puppeteer brothers practicing at home Source: Kumparan NEWS (June $3^{\text {rd }}, 2018$ )

The passage of Prama and Rafi was one of the scarce stories in preserving the Indonesian traditional arts that were carried out in Indonesian families where the family environment is the first and the crucial circumstances for building children's identity (Wibowo et al., 2020). The preservation of Indonesian traditional arts is the society's responsibility. The local people's appreciation is needed as one of the most essential factors to respect their own value and identity (Nurdiyana, 2019). The traditional value and identity have to be introduced and brightened up by family, society, and the government, from children to adults (Suryatini \& Susanthi, 2019). The collaborative work among the three components and supported by educators in formal and non-formal 
circumstances are necessary to build the best characters through the traditional heritage values as the noble national values and the authentic culture as well (Suryanto, 2017).

\section{YouTube as the Learning Media for the Duo Puppeteer Brothers}

Prama - at the age of five - and Rafi - at the age of three - started to learn and practice the puppetry arts seriously and independently. The duo puppeteer brothers started to watch their favorite puppeteer, Ki Bayu Aji, through several recordings brought by their grandfather and mother. The duo puppeteer brothers asked to meet their puppeteer's idol personally, which was finally granted when Prama was in their second year of primary school. The meeting inspired the duo puppeteer brothers to learn more and practice more. Since then, the duo puppeteer brothers have adored Ki Bayu Aji much more and never missed every performance from Ki Bayu Aji that were uploaded in the YouTube channel. When most children or teenagers watched YouTube for various movies and games, the duo puppeteer brothers watched YouTube for Ki Bayu Aji puppets' performances to watch the shows repeatedly. Through YouTube, they were comfortable and satisfied with the visualization and the audio that they could pause and repeat anytime (Hong et al., 2016; Orús et al., 2016). In this way, the use of YouTube as the media learning had been proven as the effective media and brought positive outcomes to the learners (Cahyono \& Hassani, 2019).

Learning through YouTube has been advancing yearly and bringing new excitement for young learners. The young learners could explore anything with three dimensions media that brought various colors and shapes, attracted sounds, and great contents. YouTube offers the magic of pleasure and learning sources (Setiadi et al., 2019). With the advanced technology, teachers are encouraged to catch up with the changes and utilize the digital era by integrating the digital tool and the lesson through YouTube channels (Fleck et al., 2014). Moreover, the YouTube channel facilitated diverse content from local to global issues for local audiences and global viewers (Slamet, 2014).

However, like other digital media, YouTube media would bring both sides of the coin in its utilization. Besides the benefits, YouTube content could be easily accessed and watched by young learners for any inappropriate content such as pornography and violence (Ensour, 2015). Therefore, using YouTube for young learners requires assistance from parents or family members to select proper and valuable content (Noor et al., 2020). In addition, the use of YouTube will increasingly have a positive impact when the content presented can be integrated with local values that carry messages of wisdom and kindness (F. Astuti, 2021). In this way, advanced technology with attractive media such as YouTube also contributes to building positive values of young learners' identity (Pawestri et al., 2020), as reflected on Prama and Rafi, the duo puppeteer brothers.

\section{Independent Learning for the Duo Puppeteer Brothers}

When most little puppeteers join a puppets' studio to enhance their puppeteer's skill, the duo puppeteer brothers have been learning the puppetry arts all by themselves without joining any puppets' studios. The duo puppeteer brothers have been learning the puppets almost every day during their free time at home and after completing their school homework. They could manage their time based on their individual needs and wants that are rarely found in the teenager level (Najeeb, 2013). That learning style is often called independent learning or learner autonomy or self-directed learning (Mckendry \& Boyd, 2012). 
By watching live shows and several videos, the duo puppeteer brothers were practicing the puppets' techniques. For the duo puppeteer brothers, watching and analyzing the detail of the puppets' performances could help them understand and practice the puppets' settings, stories, figures, and techniques of demonstrating the puppets. At first, the duo puppeteer brothers imitate the act (Sabet) and the voice (Suluk) of their favorite puppeteer, Ki Bayu Aji Pamungkas, the son of Ki Anom Suroto, the famous Indonesian puppeteer. It was not easy and took time to accustom the duo puppeteer brothers to the techniques. Nevertheless, by practicing regularly, the duo puppeteer brothers could show the results of their hard work (Agustina \& Fajar, 2019).

Through continuous activities and practices, in 2018, the duo puppeteer brothers were invited to India and Russia as the Indonesian Cultural Ambassador of the traditional Indonesian puppets (JABARNEWS, May 3rd, 2018). The achievements are the remarkable evidence that the duo puppeteer brothers has shown a Higher Order Thinking Skills (HOTS) level at their very young age (Djiwandono, 2017; Ertürk et al., 2016). The factor of self-motivation contributed the success of their independent learning was the primary aspect that brought them to a great achievement (Putra, 2017). In fact, selfmotivation is the key factor of any learning style to attain the best learners' outcomes (Tabiati, 2016; Vibulphol, 2016).

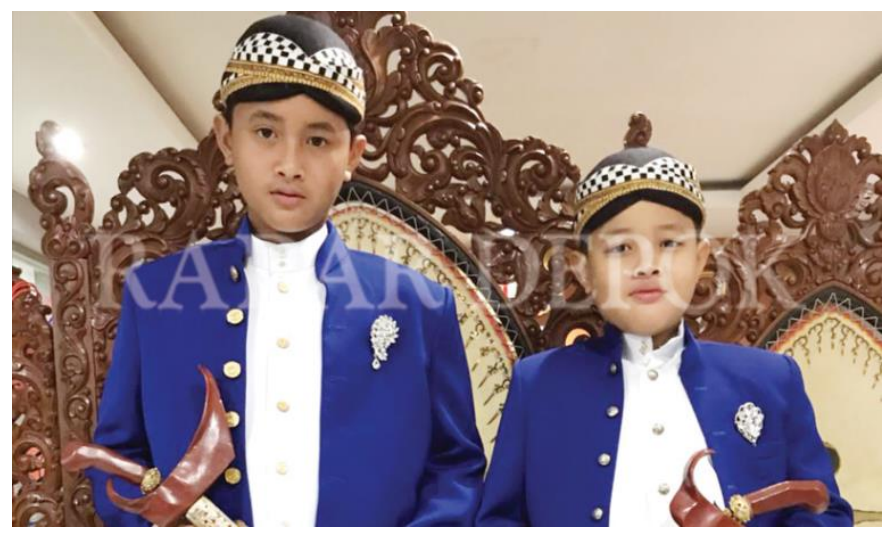

Figure 3 The Duo Puppeteer Brothers

Source: JABARNEWS (May $3^{\text {rd }}, 2018$ )

\section{CONCLUSION}

The achievements of the duo puppeteer brothers, Prama and Rafi, have proven the best practice of independent learning through YouTube, particularly in learning the puppetry arts. YouTube with plenty of channels from local and international sources, various content and performances with attractive visualized colors and shapes, and the sounds with different vocals, intonation, and music all bring the excitement and effective learning process. The utilization of that attractive digital media learning is supposed to assist parents or other family members to avoid inappropriate content and other misuse. The attractive digital media, the assistance of parents or other family members, and the high motivation of a learner will bring together the best learning experience and learning outcome of today's generation. However, this research is limited for its specific subject, object, method, time, and media. Further research is needed to discover different and comprehensive perspectives. 


\section{REFERENCES}

Agung, A. S. N., \& Surtikanti, M. W. (2020). Students' perception of online learning during covid-19 pandemic: A Case study on the english students of STKIP Pamane Talino. SOSHUM: Jurnal Sosial Dan Humaniora, 10(2), 225-235. https://doi.org/10.31940/soshum.v10i2.1316

Agustina, D., \& Fajar, D. A. (2019). The Importance and the meanings of independent learning: University students' perceptions. Vidya Karya, 33(2), 104. https://doi.org/10.20527/jvk.v33i2.5502

Astuti, F. (2021). Exploring local wisdom from youtube: An investigation on the indonesian higher education students' dance performance across gender. Cakrawala Pendidikan, 40(1), 230-241. https://doi.org/10.21831/cp.v40i1.32426

Astuti, Y. T., Lestari, W., \& Cahyono, A. (2021). Sikap siswa terhadap pembelajaran seni tari di masa pandemi covid-19. Jurnal Kajian Ilmiah, 21(1), 101-110. https://doi.org/10.31599/jki.v21i1.445

Cahyono, G., \& Hassani, N. (2019). Youtube seni komunikasi dakwah dan media pembelajaran. Al-Hikmah, 13(1), 23-38. https://doi.org/10.24260/alhikmah.v13i1.1316

Creswell, J. W. (2012). Educational research: Planning, conducting, and evaluating quantitative and qualitative research in educational research. Pearson Education Inc. https://doi.org/10.1017/CBO9781107415324.004

DeWitt, D., Alias, N., Siraj, S., Yaakub, M. Y., Ayob, J., \& Ishak, R. (2013). The Potential of youtube for teaching and learning in the performing arts. Procedia -Social and Behavioral Sciences, 103(November), 1118-1126. https://doi.org/10.1016/j.sbspro.2013.10.439

Djiwandono, P. I. (2017). The learning styles of millennial generation in university: A study in indonesian context. International Journal of Education, 10(1), 12. https://doi.org/10.17509/ije.v10i1.5085

Dua dalang cilik Depok manggung ke India sampai Rusia. (May $3^{\text {rd }}$, 2018). JABARNEWS.

Ensour, H. (2015). The effect of using youtube on youth worst and best case. British Journal of Applied Science \& Technology, 8(3), 286-304. https://doi.org/10.9734/bjast/2015/11956

Ertürk, N. O., Setyarini, S., Kemala, Z., Smith, R., Kuchah, K., \& Lamb, M. (2016). Promoting learner autonomy in teaching english to young adolescents through higher order thinking skills: An Innovation to create 4.0 learning trends. Autonomy in Language Learning and Teaching: New Research Agendas, 232(ICESSHum), 11-20. https://doi.org/10.1057/978-1-137-52998-5_2

Fleck, B. K. B., Beckman, L. M., Sterns, J. L., \& Hussey, H. D. (2014). YouTube in the classroom: Helpful tips and student perceptions. The Journal of Effective Teaching, 14(3), 21-37.

Hong, J. C., Hwang, M. Y., Szeto, E., Tsai, C. R., Kuo, Y. C., \& Hsu, W. Y. (2016). Internet cognitive failure relevant to self-efficacy, learning interest, and satisfaction with social media learning. Computers in Human Behavior, 55(February), 214-222. https://doi.org/10.1016/j.chb.2015.09.010

Imathiu, S. (2018). Use of Web 2.0 technologies as mediation tools in higher education with focus on YouTube. Current Research Journal of Social Sciences and Humanities, 1(1), 21-28. https://doi.org/10.12944/crjssh.1.1.03

Iswinarti, \& Suminar, D. R. (2019). Improving children's problem-solving skills through 
javanese traditional games. Cakrawala Pendidikan, 38(3), 578-589. https://doi.org/10.21831/cp.v38i3.25331

Kaunang, M. S. C. (2020). Manajemen pembelajaran musik siswa MIS (Manado Internasional School) secara virtual di Era Kenormalan Baru. Pelataran Seni, 5(2), 103-109. https://doi.org/10.20527/jps.v5i2.9126

Kennedy, Ü. (2016). Exploring youtube as a transformative tool in the "The Power of MAKEUP!" Movement. M/C Journal, 19(4). https://doi.org/10.5204/mcj.1127

Mansyur, A. R. (2020). Dampak covid-19 terhadap dinamika pembelajaran di Indonesia. Education and Learning Journal, 1(2), 113-123. https://doi.org/10.33096/eljour.v1i2.55

Mckendry, S., \& Boyd, V. (2012). Defining the "Independent Learner" in UK Higher education: Staff and students' understanding of the concept. International Journal of Teaching and Learning in Higher Education, 24(2), 209-220.

Meski sering pentas, nilai sekolah duo dalang cilik ini tetap baik. (June $3^{\text {rd }}, 2018$ ). KumparanNews.

Mujianto, H. (2019). Pemanfaatan youtube sebagai media ajar dalam meningkatkan minat dan motivasi belajar. Jurnal Komunikasi Hasil Pemikiran Dan Penelitian, 5(1), $135-159$.

Najeeb, S. S. R. (2013). Learner autonomy in language learning. Procedia - Social and Behavioral Sciences, 70, 1238-1242. https://doi.org/10.1016/j.sbspro.2013.01.183

Noor, F., Mumpuni, R. A., Amaliyah, A., \& Laksmiwati, I. (2020). Pendampingan ibu bekerja (working mom) terhadap penggunaan youtube pada anak. Komuniti: Jurnal Komunikasi Dan Teknologi Informasi, 12(1), 40-50. https://doi.org/10.23917/komuniti.v12i1.10070

Nurdiyana, T. (2019). Wayang tengul art performance: A study of people's appreciation of wayang tengul art. Harmonia: Journal of Arts Research and Education, 19(2), 163-171. https://doi.org/10.15294/harmonia.v19i2.23636

Orús, C., Barlés, M. J., Belanche, D., Casaló, L., Fraj, E., \& Gurrea, R. (2016). The effects of learner-generated videos for YouTube on learning outcomes and satisfaction. Computers and Education, 95(April), 254-269. https://doi.org/10.1016/j.compedu.2016.01.007

Pangestika, F. Y., \& Yanuartuti, S. (2020). Pembelajaran mandiri seni tari melalui konten youtube sebagai inovasi pembelajaran masa kini. Gondang: Jurnal Seni Dan Budaya, 4(2), 144-151. https://doi.org/10.24114/gondang.v4i2.18098

Pawestri, A. G., Thanissaro, P. N., Kulupana, S., Istiani, A. N., Widhiyatmoko, Y. Y., Raden, U., Lampung, I., \& Lampung, U. (2020). Membangun identitas budaya banyumasan melalui dialek ngapak di media sosial. Jurnal Pendidikan Bahasa Dan Sastra, 19(2), 255-266. https://doi.org/10.17509/bs_jpbsp.v19i2.24791

Pratama, D. (2011). Wayang kreasi: Akulturasi seni rupa dalam penciptaan wayang kreasi berbasis realitas kehidupan masyarakat. Deiksis, 3(4), 379-396. https://doi.org/http://dx.doi.org/10.30998/deiksis.v3i04.442

Pratiwi, B., \& Puspito Hapsari, K. (2020). Kemampuan berpikir tingkat tinggi melalui pemanfaatan youtube sebagai media pembelajaran bahasa Indonesia. Jurnal Ilmiah Sekolah Dasar, 4(2), 282-289. https://doi.org/10.23887/jisd.v4i2.24238

Putra, R. A. (2017). Penerapan metode pembelajaran mandiri dalam meningkatkan hasil belajar peserta didik (studi pada program pendidikan kesetaraan paket C di PKBM Bina Mandiri Cipageran). Jurnal Pendidikan Luar Sekolah, 13(1), 23-36. 
Ramdhani, A., \& Ahmad, H. A. (2017). Penerapan teknologi $360^{\circ}$ Video dan virtual reality pada pertunjukan wayang golek cepak Tegal. SENIT, 2(1), 17-23.

Ruastiti, N. M., Sudirga, I. K., \& Yudarta, I. G. (2020). Model of innovative wayang wong for millenial generation to meet 4.0 industrial revolution era in Bali. Journal of Environmental Treatment Techniques, 8(3), 999-1004.

Sari, L. (2020). Upaya menaikkan kualitas pendidikan dengan pemanfaatan youtube sebagai media ajar pada masa pandemi covid-19. Jurnal Tawadhu, 4(1), 10741084.

Setiadi, E. F., Azmi, A., \& Indrawadi, J. (2019). Youtube sebagai sumber belajar generasi milenial. Journal of Civic Education, 2(4), 313-323. https://doi.org/10.24036/jce.v2i4.135

Slamet, Y. B. M. (2014). Constructing a course on indonesian shadow puppets for international students. Celt: A Journal of Culture, English Language Teaching \& Literature, 14(1), 16. https://doi.org/10.24167/celt.v14i1.54

Suryanto, E. (2017). Model pendidikan karakter berbasis pembelajaran apresiasi cerita rakyat dengan menggunakan media wayang kancil. Jurnal Pendidikan Bahasa Dan Sastra, 17(2), 260-274. https://doi.org/10.17509/bs_jpbsp.v17i2.9663

Suryatini, N. K., \& Susanthi, N. L. (2019). Rare kelangon the innovation of gender wayang colosal for children. Lekesan: Interdisciplinary Journal of Asia Pacific Arts, 2(2), 68-79. https://doi.org/10.31091/lekesan.v2i2.891

Tabiati, S. E. (2016). Factors contributing to learners' autonomy in EFL reading. Jurnal Pendidikan Humaniora, 4(2), 82-94.

Vibulphol, J. (2016). Students' Motivation and Learning and teachers' motivational strategies in english classrooms in Thailand. English Language Teaching, 9(4), 64-75. https://doi.org/10.5539/elt.v9n4p64

Wibowo, A., Kurnain, J., \& Juanda, J. (2020). History of inheritance of wayang topeng malangan (malang traditional mask puppet) in Pakisaji and Tumpang. Harmonia: Journal of Arts Research and Education, 20(1), 73-83. https://doi.org/10.15294/harmonia.v20i1.24785 